\title{
Business Web: Discovering Corporate Links
}

Sambhavi Lakshminarayanan, Medgar Evers College, CUNY

Michael Rain, Columbia University

\begin{abstract}
Business education requires students to have knowledge about corporations and the relationships between them. Sometimes students, in particular non-traditional ones, may not have either this knowledge or the skills required to obtain it. The Business Web guides students in acquiring information about businesses and understanding their inter-connections. As they build Business Webs, students are also trained in knowledge management - acquiring, evaluating and using domain related information. The Business Web is a simple, powerful, flexible and student driven tool, with potential for general use.
\end{abstract}

Keywords: tool, non-traditional, student driven, web, business network, corporate

\section{INTRODUCTION}

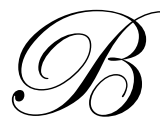

usiness education has altered over the years, both in content and delivery, in response to changing market demands (Locke 1998). In particular, education has become more information intensive and students are expected to be increasingly adept at "knowledge management". Knowledge Management can be broadly understood to refer to collection and utilization of information, and more precisely as "understanding the relationships between data, identifying and documenting rules for managing data, assuring that data are accurate and maintaining integrity" (Velthouse and Taghaboni-Dutta).

Over the years large corporations and business schools have become increasingly intertwined (Johnson 1992, Lorange 2002). As corporations play a bigger role as primary clients, there is greater stress on relating business education to the corporate world (Porter and McKibbin 1988). Indeed, Johnson (1992) urges business schools to "recognize their real customers, society's business organizations and the graduates they hire". Indeed, a business school could even become a corporation's "learning partner", with curriculum focused on the corporation's needs (Lorange 2002). Conversely, a business organization could establish a "corporate university" for the same purpose (Allen 1996). This close linkage extends to specialized institutions such as HBCUs as well, who have pursued corporate connections and forged them in special ways (Berry 2007, Buzzetto-More and Sweat-Guy 2006, Roach 2001, Special Section 2001).

There also are deeper and more implicit links between businesses and education. Textbooks in the discipline are sprinkled with illustrative examples of corporate actions (see for example: Kreitner 2007, Schermerhorn, Hunt and Osborn 2005). The widely used "case" method, and its modifications, aimed at giving students a flavor of real world business, often describes corporations (David 2007, Kilbane, Theroux and Sulej, 2004, Richardson and Ginter 1998, Rowe 2007). Other methods like the experiential approach (McCarthy and McCarthy 2006) further build on the interaction between students and businesses.

These close links necessitate that students have knowledge and information about corporations. As the business landscape changes, such knowledge has to be dynamically and continually updated. Students need to know not only what specific organizations do, but also how they affect each other and the business environment; for instance, that businesses often function as parts of networks (Bernstein 1998, Iberra and Hunter 2007) or clusters (Porter 1998).

The Business Web is a simple, flexible and powerful method to systematically build knowledge about the business world. It requires students to search for business related information, evaluate it and use it to understand 
inter-corporate relationships. With a focus on gaining knowledge about specific companies and links between them, the Business Web simultaneously builds knowledge and strengthens knowledge management skills.

Initially, the Business Web was developed in response to needs of non-traditional students. "Nontraditional student" is commonly taken to mean a student who has not followed the path of completing college education immediately following high school. This group includes those continuing an interrupted college program, full-time employees enrolled in evening or weekend programs, international students who may or may not overlap with these categories and many others. Educating non-traditional students has taken on greater importance as the percentage of "traditional" students declines in colleges (Kennen and Lopez, 2005). In particular, non-traditional and minority students have educational requirements that need focused approaches, methods and tools (see for example: Sheu and Wong 2006). As business students, they may not be very familiar with aspects of the business world, particularly large corporations. In order to obtain the maximum advantage of their education, these students need to quickly acquire such business knowledge in a reliable way. The Business Web was developed in response to this need and has been implemented for several semesters at an urban four-year college with an overwhelming proportion of international and minority students (Snapshot 2003-2004).

\section{DESCRIPTION OF THE BUSINESS WEB AND PARAMETERS}

Every Business Web starts with a "seed" company and grows with the addition of more companies to the web via links. These links are based on the (current) business environment and are connections between businesses such as supplier, subsidiary and distributor.

Appendix A is the handout that students receive on how to start and build the web.

The two major components to building a Business Web are:

Step 1: Obtaining Company Specific Information.

The student obtains key information about a particular company. Information sources could be company websites or business related databases. Companies that are researched in this manner become part of a list that is maintained implicitly in the web.

\section{Step 2: Identifying Links}

The student scans business news to find items that relate to companies already researched (that are on the list). The student then selects a "new" company that appears in such a news item; and adds it to the list while identifying the company it is linked to. It is important that the links used be relevant, reliable and timely. Information sources could be established business publications and business news related databases

Step 1 ensures that students become familiarized with individual companies; step 2 that they identify and understand relationships between them.

The Business Web can be altered to fit the needs of a particular student group, course of study or educational goal. This can be done through choice of parametric values, where the parameters are identified through the following questions.

The first set of questions relates to the "quality" of the product; that is, the webs.

Question 1a: Question 2a: Question 3a:
Should students be allowed to choose seed companies or should these be assigned?

What information should be obtained about a particular company?

What are acceptable links between businesses? To what level of detail should these links be reported? 
Question 4a: How many new companies should be added to the web at a time; that is, how fast should it be grown?

Question 5a: Should webs be built as individual webs? Should individual webs be connected? Should webs be built as a group exercise?

Question 6a: What are acceptable sources to get information about companies and links between them?

Question 7a How recent should the information be? In particular, this relates to the links, which are based on business news.

The second set relates to the process of building the Business Web.

Question 1b: What are methods through which students can access information from sources identified as acceptable?

Question 2b: How frequently should new companies are added to web?

Question 3b: Should students work individually or in groups in creating a Business Web?

Question 4b: How frequently should students report back on the status of their Business Webs?

Question 5b: To what extent should students be guided in the process of building their Business Webs? Should it be instructor directed with more predictable outcomes and potential for future discussions or student driven with greater degree of experimentation and self-learning?

The last set relates to the presentation of the Business Web.

Question 1c: What should be the medium through which webs are built? Should it be paper (chart paper) or paper free and electronic?

Question 2c: $\quad$ What are appropriate software for building Business Webs?

Question 3c: Should students individually present and describe their Business Webs or should the presentation be an exhibit?

There are clear goals to implementing the Business Webs. These are, for students to:

a. independently research and obtain information about business organizations.

b. understand how businesses are inter-related - the degree of impact they have on each other and the types of relationships that exist.

c. identify reliable sources of business information and access them.

d. (as a corollary to above) critically evaluate such information.

e. $\quad$ conduct searches in efficient and effective ways.

f. gain new or improve existing technological skills - such as presentation software.

The over-arching goal is for students to gain deeper understanding of the dynamic nature of the world of business.

\section{IMPLEMENTATION DETAILS}

As mentioned, the Business Web has been implemented in different courses in the business program, including - Principles of Management (MAN 211), Essentials of Marketing (MAR 231), Organizational Behavior (MAN 314) and Operations Management (MAN 351). Descriptions of these courses can be found in Medgar Evers College (2005-2008).

Initial implementation stages were experimental with a definite learning curve over time. In the very first implementation, students were allowed complete choice - of seed companies, information sources and kinds of links they wanted to explore. However, that resulted in Business Webs of highly variable quality. Some students' webs were based on reliable and current information, but many were of poor quality and were weak or based on information of questionable reliability; such as outdated information about an acquisition that was later divested. 
The initial experience led to a tightening of the process, with more guided direction from the instructor. For instance, Question 7a is an important determinant of quality of the webs and has most impact in presenting current business environments. In answer to Question 6a, students were asked to attend a special class in the library where the librarian showed them how to access databases for information. An important change was in the answer to Question 1a- students were either assigned specific companies or decided on seed companies in consultation with the instructor. In one class, where there were about 30 students, each was randomly assigned a seed company from the group that forms the Dow Jones Industrial Average (Data Monitor). This strategy had many benefits, which are described in a later section.

To keep students focused and to speed up web creation, in regard to Question 2a, it was decided that three key pieces of information about each company would be sufficient. These were: when the company was started, the industry(ies) it competes in and the current CEO. These terms were subject to interpretation; for example, "started" could mean when it was incorporated, but could also be when it had an IPO. Students did need guidance for Question 3a; in one course, a list of just five acceptable links was given to them. In general, acceptable links included supplier, partner, competitor and subsidiary. For instance, students were told that if the only connection between two companies was that they were mentioned in the same context (for example: that both had lower sales than expected due to a slow down of the economy), it did not constitute a link.

Growing Business Webs at the rate of 3 a week was deemed appropriate; this answered both Questions 4a and $3 \mathrm{~b}$. This would not tax the students much, yet add enough new companies to get a rich web. Certain implementations were run for the entire semester, for about 10 weeks, so that resulting webs had anywhere from 30 to 50 companies, depending on student enthusiasm. In one implementation, students built individual webs for 5 weeks, so each had 15 companies. The class was then randomly divided into groups and students "joined" their webs to form group webs. Finally all the group webs were joined to form a class web, which was put up as a classroom display. In this class of about 30 students, this resulted in about $30 * 15=450$ companies. Even discounting for overlaps, which were not as many as expected, this was a substantial number of organizations.

Appendix B shows a sample student web that was built in the MAN 351 course. The seed company of this web was Johnson and Johnson. In this case the seed company had many links, but that need not be the case in general. Later in the semester, this web was connected to other webs in the class.

As implementation continues, various parameters of the Business Web are constantly being changed in order to improve and strengthen it as a teaching/learning tool.

\section{CONNECTION TO TEACHING PEDAGOGIES}

Although the Business Web was created primarily in response to student needs, it has strong theoretical underpinnings. For instance, the web encourages students to become teachers (Garvin 1991) - for themselves, peers, and the instructor.

The main characteristics of the web as a teaching and learning tool are:

a. emphasis on student-centered and student-driven learning

b. development of knowledge management skills: acquiring information and critically evaluating it for accuracy, reliability and relevance

c. knowledge acquisition in domain of study

The Business Web is a tool that helps in formulating responses to key questions related to business education, such as: "what do we want students to think about and why? What do we want students to be able to do?" (Dehler, 1996).

With regard to taxonomy, the Business Web contributes to several "knowledge dimensions" (Anderson and Krathwohl 2001). First, it helps students increase factual knowledge through gathering basic information important 
to the discipline. Second, since students have to investigate links between businesses, the web also helps develop conceptual knowledge - for example in classifying businesses by industry. Finally, it provides students with procedural knowledge by training them in methods of obtaining business related information and identifying reliable sources. Thus, it contributes to students' remembering, understanding, evaluating and analyzing business information.

As a form of active learning where students get to know the practical aspects of business, the Business Web falls into Quadrant III of classification of teaching tools in Randolph and Posner (1979) and indeed could be considered as a "structured exercise". As a caveat, we mention that it has to be used in conjunction with other teaching methods in order to attain student learning objectives, particularly when students need skills training to attain these objectives (based on recommendations in Randolph and Posner, 1979).

The Business Web fits in well with the pedagogy of information search. Students go through different learning stages before they become expert at conducting searches (O'Sullivan and Scott 2005) and the Business Web leads students through various levels of this process through repeated searches. Finally, Lazonder (2005) considered the advantages of collaboration in searching. The Business Web can be adapted easily to be a group activity with students either working together from the beginning on one web or incrementally joining up webs.

\section{ASSESSMENT OF THE BUSINESS WEB}

The Business Web as a teaching and learning tool was created in response to specific student needs. As mentioned, these were students who fall in the "non-traditional" category, and who neither had familiarity with many business organizations frequently cited in textbooks, nor had developed skills of gaining (domain specific) business information.

A precursor to the Business Web was an assignment that required students to research and present information about only one company; this had mixed results in terms of student enthusiasm and quality of material presented. Students responded much more favorably to the more complex Business Web concept. They were told very clearly that the idea originated from a student like themselves; this played a big role in breaking down barriers to implementation.

In some classes, Business Webs were customized to tie in with the rest of the course material. Thus, students were asked to find marketing related links in MAR 231 (Essentials of Marketing). In another implementation, students were assigned seed companies based on the Dow Jones Industrial Average (DJIA). Students became educated about how it was computed, and more generally about indices. Also, since these companies are distributed across industries, there was a wide base over which the individual webs were spread. In this class, all individual student webs were eventually linked; thus the final web illustrated a major portion of the economy.

The most immediate way to assess the Business Web is to simply examine student created webs and their information quality. Since webs are to be based on business news, the presence of well-known, large corporations in them is an indication that students have followed directions. Educational experience of students is clearly indicated by quality of the links. Students in more advanced classes should be, and usually are, able to identify "better" and stronger links, even ones particular to a subject area such as marketing. Inexperienced students often include weak links and smaller, less-known companies which offer few opportunities to grow the web further.

Students in some classes were administered a simple survey (Appendix C). Most often, students listed company websites, business periodicals websites and databases such as Hoover and Academic Search premier as sources of information. On average, students rated the difficulty level of creating webs at " 3 "- moderately difficult. In terms of usefulness, the average rating was 4.5. This can be interpreted to mean that students felt it was worth the time invested and that it would help in their business education. In response to what they learned, the most common response was about exactly how, and the extent to which, businesses are linked to each other. 
These first level assessments were very encouraging and showed us that students had grasped the concept of the tool, were able to implement it well and felt that what they had learned was useful.

\section{CONCLUSIONS AND FUTURE RESEARCH}

The Business Web is a simple, yet powerful and flexible tool. It is anchored in teaching pedagogies and we hope is a reliable method to help achieve teaching and learning goals in business courses.

The Business Web can be customized to fit various educational needs, enhance the course material and the educational experience. It can be used for both training and learning; that is, to provide knowledge as well as skills. With increasing implementation, it is likely that a student will be required to build Business Webs in different classes and will gain expertise in it. Students in general are becoming more skilled in accessing information and need much less direction than they used to. Thus, with increasing implementation of the Business Web, higher level courses should see a shift in focus away from the mechanics of building webs to the quality of webs built. Concurrently, the Business Web exercise can be made more closely related to course material. Students can be asked to include specific information in their webs, such as particular types of links, industries and business organizations. For instance, a course on international management could have students starting with companies in different countries.

The Business Web also lends itself easily to be a group exercise. As indicated in Lazonder (2005), group searches are often of better quality than individual ones and we would expect that to result in better quality webs. Group effect is present even when students build individual webs, with a great degree of peer-to-peer learning. Students routinely exchange information about good sources of information or better software to create webs in.

An important advantage of the Business Web is the self-efficacy students feel with mirroring increase in their interest in the area of study. The "agentic" perspective (Bandura 2001) would indicate that since students develop the webs by themselves, they will tend to be more actively involved in their own development. In particular, non-traditional students face challenges in this regard (Mayo and Christenfeld 1999). The Business Web has no "right" answer and students have complete control over the content and quality of their webs, while having ample scope to be creative.

In future research, we plan to have stronger assessment tools for the Business Web. Since a goal is to increase student knowledge of business organizations, pre- and post- surveys that measure this would be extremely useful. We also plan to have student webs available for sharing across courses, so that all instructors and students can benefit from the store of information contained in them. Viewing webs across time would provide both a historical perspective and valuable information on how business environments change.

In conclusion, we believe the Business Web has the potential and power to be a critical tool in teaching business. Unintended, yet important benefits, such as improvement in key technological skills and increase in selfconfidence for students, make it effective as a general purpose teaching tool as well. 


\section{APPENDIX A}

\section{Building a Business Web}

A tool for increasing your corporate business knowledge

GOAL : To increase familiarity with corporate businesses by building a network / "web" that links different corporations to one another.

HOW TO BUILD A BUSINESS WEB:

- Start with one company.

- Give a brief description of the company listing 3 pieces of information -

$\circ$ Date established (or when it had an IPO)

- What industry it is in

- Who the CEO is

- Each week: find 3 companies that are related in some way to the ones you ALREADY have on the web. You will need to get this information from news sources such as newspapers, magazines etc.

- Add the new companies via link and describe the relationship on it.

- For every new company that you add to the web, list the 3 pieces of information as above.

\section{AN EXAMPLE}

\section{STARTING "COMPANY" Week 1}

YAHOO -

Established: 1995

Industry: Web Search Portal

CEO (President): Jerry Yang

\section{GROWING THE WEB - Week 2}

\section{YAHOO}

Established: 1995

Industry: Web Search Portal

CEO (President): Jerry Yang
New York Times

Established: 1896

Industry: Media/ Newspaper

CEO (President): Arthur O. Sulzberger,

Jr.

\section{NETFLIX}

Established: 1997

Industry: Retail/ Media

CEO (President): Reed Hastings

\section{GOOGLE}

Established: 1998

Industry: Web Search Portal

CEO (President): Dr. Eric Schmidt 


\section{APPENDIX B}

Sample Student BUSINESS WEB, Spring 2007

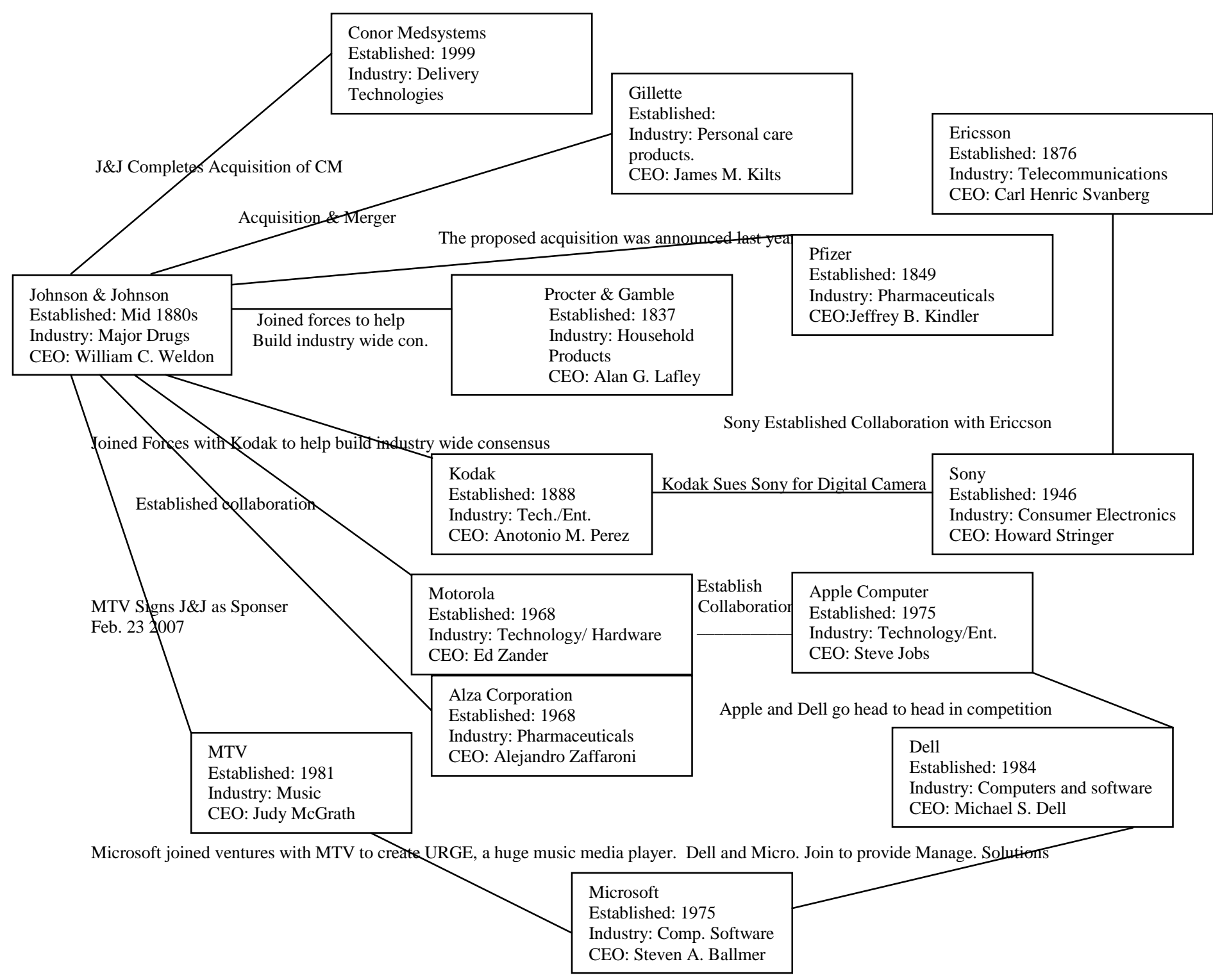




\section{APPENDIX C \\ Business Web \\ Post-Implementation Feedback}

Your name:

1. Approximately how many companies did you have on your web?

2. Approximately how many hours did you spend on creating the web?

3. Where did you find information about the companies?

List as many sources as you can remember.

4. Rate the difficulty level of creating this web.
Very easy
1
2
3
Very difficult
$4 \quad 5$

5. Rate how USEFUL the exercise in creating the web was to you.

\begin{tabular}{llllr} 
Completely & & & & Extremely \\
Useless & 2 & 3 & 4 & 5 \\
1 & & & 4 & \\
\hline
\end{tabular}

6. List 3 things you learned from your experience with creating the web.

7. What suggestions do you have for improving the use of the business web as a classroom teaching/learning tool?

\section{AUTHOR INFORMATION}

Sambhavi Lakshminarayanan is currently a faculty member in the School of Business at Medgar Evers College, CUNY. Dr. Lakshminarayanan has wide experience in teaching business school students - at the undergraduate, graduate (MBA) and post-graduate (PhD.) levels. Dr. Lakshminarayanan has conducted research related to models (quantitative and qualitative) in the area of business and in their applications, particularly as related to diversity. A continuing area of interest is exploring pedagogies and techniques in the teaching of business, to traditional as well as non-traditional students.

Michael Rain was a student of the first author, at Medgar Evers College, when they began collaboration to design and implement a teaching and learning tool that would be effective for non-traditional business students. Mr. Rain is currently a student at Columbia University with an interest in exploring and working in the area of social responsibility and responsiveness of Corporations.

\section{REFERENCES}

1. Allen, C. (1996). Corporations Grow Their Own Best Employees at Corporate Universities. In Locke, R. R. (ed) (1998) Management Education: History of Management Thought. Dartmouth Publishing Group.

2. Anderson, L., \& Krathwohl, D. (2001). A Taxonomy for Learning, Teaching and Assessing: A Revision of Bloom's Taxonomy of Educational Objectives. Longman: New York.

3. Bandura, A. (2001). Social Cognitive Theory: An Agentic Perspective. Annual Review of Psychology, $52(1), 1-25$.

4. Berry, J. M. (2007). HBCUs and Black Investment Banks: A Natural, Transformative Partnership. Diverse Issues in Higher Education, 24(6), 19.

5. Bernstein, P.L. (1998). Are Networks Driving the New Economy. Harvard Business Review, 76(6), 159166. 
6. Buzzetto-More, N. A., \& Sweat-Guy, R. (2006). Incorporating the Hybrid Learning Model into Minority Education at a Historically Black University. Journal of Information Technology Education, 5, 153-164.

7. David, F. (2007). Strategic Management: Cases. Eleventh Edition, Pearson Prentice Hall: New Jersey.

8. Dehler, G. E. (1996). Management Education as Intentional Learning: A Knowledge-Transforming Approach to Written Composition. Journal of Management Education, 20(2), 221-235.

9. Data Monitor, Retrieved October 24, 2007, from http://www.computerwire.com/companies/lists/list.

10. Garvin, D. A. (1991). Barriers and Gateways to Learning. In C. R. Christensen, D. A. Garvin \& A. Sweets (Eds.) Education for Judgment: The Artistry of Discussion Leadership. Harvard Business School Press: Boston.

11. Ibarra, H. \& Hunter, M. (2007). How Leaders Create and Use Networks. Harvard Business Review, 85(1), 40-47.

12. Johnson, H. T. (1992). New Frontiers for Business Education. In Locke, R. R. (ed) (1998) Management Education: History of Management Thought. Dartmouth Publishing Group.

13. Kennen, E. \& Lopez, E. (2005). Finding Alternate Degree Paths for Non-Traditional, Now-Traditional Students. The Educational Digest, 70(8), 31-35.

14. Kilbane, C., Theroux, J. \& Sulej, J. (2004). The Real-Time Case Method: Description and Analysis of the First Implementation. Innovative Higher Education, 29(2), 121-135.

15. Kreitner, R. (2007). Management, Tenth Edition. Houghton Mifflin

16. Lazonder, A. W. (2005). Do Two Heads Search Better than one? Effects of Student Collaboration on Web Search Behavior and Search Outcomes. British Journal of Education Technology, 36(3), 465-475.

17. Lorange, P.(2002). New Vision for Management Education: Leadership Challenges. Pergammon, imprint of Elsevier Science.

18. Mayo, M. W. \& Christenfeld, N. (1999). Gender, Race and Performance Expectations of College Students. Journal of Multicultural Counseling and Development, 27(2)2, 93-102.

19. Medgar Evers College. (2005-2008). College Catalogue, Medgar Evers College, The City University of New York, 1650 Bedford Avenue, Brooklyn, NY, 56-62.

20. McCarthy, P. R. \& McCarthy, H. M. (2006). When Case Studies Are Not Enough: Integrating Experiential Learning Into Business Curricula. Journal of Education for Business, 81(4), 201-204.

21. O’Sullivan, M. K. \& Scott, T. J.(2005). Analyzing Student Search Strategies: Making a Case for Integrating Information Literacy Skills into the Curriculum. Teacher Librarian, 33(1), 21-50.

22. Porter, L. W. \& McKibbin, L. E. (1988). Management Education and Development: Drift or Thrust into the $21^{\text {st }}$ Century? McGraw Hill: New York, 332-333.

23. Porter, M. (1998). Clusters and the New Economics of Competition. Harvard Business Review, 76(6), 7790.

24. Randolph, A.\& Posner, B. Z. (1979). Meaningful Learning Situations in Management: A Contingency Tree Approach. Academy of Management Review, 4(3), 459-467.

25. Richardson, W. D. \& Ginter, P. M. (1998). Using Living Cases to Teach the Strategic Planning Process. Journal of Education for Business, 73(5), 269-273.

26. Roach, R. (2001). A Model Project. Black Issues in Higher Education, 18(20), 26-28.

27. Rowe, G. W. (2007). Cases in Leadership, Sage: Los Angeles.

28. Schermerhorn, J. R. Jr., Hunt, J. G. \& Osborn, R. N. (2005). Organizational Behavior. Ninth Edition, John Wiley and Sons Inc.

29. Sheu, M. Z. \& Wong, W. (2006). A Knowledge Assimilation Schema for Acquiring Technical Knowledge. Journal of Information System Education, 17(2), 223-229.

30. Snapshot. (2003-2004). Institutional Assessment, Planning and Accountability, Medgar Evers College, CUNY: New York.

31. Special Section. (2001). The Business of Teaching Business. Black Issues in Higher Education, 18(20), 2646.

32. Velthouse, B.\& Taghaboni-Dutta, F. E-education and Knowledge Acquisition: Pedagogy vs. Technology. International Journal of Knowledge, Culture and Change Management, Electronic, 5(4), 209-214. 